\title{
Trophic relationships in fish assemblages of Neotropical floodplain lakes: selectivity and feeding overlap mediated by food availability
}

\author{
Rosa Maria Dias, Jean Carlo Gonçalves Ortega, Luiz Carlos Gomes \& Angelo Antonio Agostinho
}

Núcleo de Pesquisas em Limnologia, Ictiologia e Aquicultura (Nupélia), Departamento de Biologia, Programa de Pós-Graduação em Ecologia de Ambientes Aquáticos Continentais, Universidade Estadual de Maringá, Av. Colombo, 5790, 87020-900, Maringá, PR, Brazil. (rmdias2003@yahoo.com.br)

Received 13 June 2016

Accepted 13 September 2017

DOI 10.1590/1678-4766e2017035

\begin{abstract}
The relationships between the degree of dietary overlap and food availability, and implications for food selectivity of fish species were evaluated at floodplain lakes on the upper Paraná River floodplain, Brazil. The hypothesis tested were: i) species become less selective in lakes with high availability of food resources; and ii) species (interspecific) or individual (intraspecific) present higher food overlap in conditions of high availability of food resources. In general, with the results was observed that species become less selective when the environment provided higher availability of food resources. Interspecific overlap did not show a pattern when evaluating availability of food resources in the lakes. However, intraspecific overlap tended to be more accentuated in conditions of high availability of resource food.
\end{abstract}

KEYWORDS. Fish feeding, electivity, Paraná River.

RESUMO. Relaç̃es tróficas em assembleia de peixes em lagoas de planície de inundação Neotropical: seletividade e sobreposição alimentar mediada pela disponibilidade de recursos alimentares. As relações entre o grau de sobreposição alimentar e disponibilidade de alimentos, e as implicações para a seletividade alimentar de espécies de peixes foram avaliadas em lagoas da planície de inundação do Alto rio Paraná, Brasil. As hipóteses testadas foram: i) as espécies tornam-se menos seletivas em lagoas com alta disponibilidade de recursos alimentares; e ii) espécies (interespecífica) ou indivíduos (intraspecífica) apresentam maior sobreposição alimentar em condições de alta disponibilidade de recursos alimentares. Em geral, com os resultados observou-se que as espécies se tornam menos seletivas quando o ambiente proporciona maior disponibilidade de recursos alimentares. A sobreposição interespecífica não demostrou padrão quando avaliado a disponibilidade de recursos alimentares nas lagoas. No entanto, a sobreposição intraespecífica foi mais acentuada nas condições de elevada disponibilidade de recursos alimentares.

PALAVRAS-CHAVE. Alimentação de peixes, eletividade, rio Paraná.

Tropical river-floodplain systems show strong and predictable seasonality in their hydrological regime, with marked consequences for the quality, stability and spatial connectivity of the habitats (JUNK et al., 1989; THOMAZ et al., 2007), which explains their high species diversity (WINEMILLER, 1996). Trophic interactions in food chains in these systems have received increased attention in recent decades, and constitute an efficient approach for improved understanding of the structure of aquatic communities (PoLIS \& Winemiller, 1996; Petchey et al., 2010; Downing et al., 2014; Pendleton et al., 2014; Binzer et al., 2015).

The interactions that commonly appear to structure tropical fish assemblages are the biotic effects of competition for resources (e.g., food and space) and predation (JACKSON et al., 2001; SCARABOTTI et al., 2011), in addition to abiotic factors such as water quality and chemistry (BouvieR et al., 2009; WinemiLler et al., 2010; DitTRICH et al., 2016). However, in natural environments, it is difficult to determine relationships, such as competition, mainly because of the lack of information about the availability of food resources in the environment. This information may be useful in determining whether, and to what degree, two or more species and/or individuals of the same species compete for the same resource. Different indices of overlap have often been employed as tools to make inferences about competition (Marçal-Simabuku \& Peret, 2002; Galina \& Hahn, 2003; RöPKE et al., 2014). However, the relationship between food overlap and availability of resources, and, therefore, its implications for competition, is a controversial subject. The question raised by Lowe-MCCONNELL (1987) about the conditions (scarcity: individuals would be compelled to use the same resources; or abundance of resources: they can be shared) in which overlap is most pronounced, still lacks an unequivocal answer.

Although food availability operates at individual level (BolNICK et al., 2010; SvANBÄCK et al., 2011), the effects of the variability of resources can be perceived at population or community levels (e.g., BoLNICK et al., 2010; Martin \& Pfennig, 2010). Theoretically, when resource availability is low, individuals can feed on a wider array of items (MarTin \& PfenNig, 2010; Araúso et al., 2011) and thus reducing the overlap among individuals of the same 
population or species. This can particularly occur when there is high feeding plasticity (ability to feed on several types of resources). Although feeding plasticity is very conspicuous in fishes of tropical environments (ABELHA et al., 2001; UIEDA \& PINTO, 2011), there is evidence that some of these fish show a certain degree of feeding specialization (LowEMcConnell, 1987; MÉrona \& RANKIN-DE-MÉrona, 2004; ARAúJo et al., 2011). Dietary plasticity can be inferred by the low degree of selection that a species shows in relation to the available resources. In general, it will consume the most abundant resources, and therefore will be less affected by competition.

The objective of this study was to determine the relationship between food item selection and overlap with the availability of food resources, as measured by the total bulk of items present in the stomachs of fish in six isolated floodplain lakes in the upper Paraná River floodplain. To avoid possible bias due to temporal variation (MedeIros \& ARTHINGTON, 2014), samplings were concentrated in a very short period of time. The following hypothesis were tested: i) species become less selective in lakes with high availability of food resources; and ii) species (interspecific) or individual (intraspecific) present higher food overlap in conditions of high availability of food resources. The predictions were: (i) feeding selectivity of the species will be lower when the availability of food resources is high; (ii) interspecific feeding overlap will be higher when the availability of food resources is higher; and (iii) intraspecific feeding overlap will be higher when the availability of food resources is also higher.

\section{MATERIAL AND METHODS}

Study area. Samplings were carried out in six floodplain lakes (Carioca, Genipapo, Zé Marinho, Cidão, Tião and Canal do Meio) located on the floodplain of the upper Paraná River. All lakes were isolated from the river during sampling (Fig. 1). They are relatively close to the main river channel (within $200 \mathrm{~m}$ ), small (maximum area: 0.5 ha) and shallow (maximum depth: $1.1 \mathrm{~m}$ ). During sampling, lakes had low transparencies (Secchi depth $<40 \mathrm{~cm}$ ), low dissolved oxygen contents $\left(<2.5 \mathrm{mg} \mathrm{L}^{-1}\right)$ and nearly constant water temperatures (close to $25^{\circ} \mathrm{C}$ ). Macrophyte cover was about $35 \%$, except for Canal do Meio Lake which had extensive plant coverage ( $85 \%$ ).

Sampling and data analysis. To minimize seasonal and daily (especially terrestrial insects) variations in food availability, samplings were collected once in April 2002, during the morning (one sample in each floodplain lake; from 07:00 to 11:00 hours). Seining nets (50 m long; $2.4 \mathrm{~m}$ high; $0.5 \mathrm{~cm}$ mesh size between opposite knots) were used to isolate sampling areas (open and macrophyte covered) in each lake to better represent the samples. These nets were set on the bottom of the lakes (attached to the margins) 24 $\mathrm{h}$ before sampling. Then, each net was lifted to enclose the area to block fish passage. Inside each area, fish were captured with small seining nets (open areas) and sieves (macrophyte covered areas). Once several species may exhibit movements between open and macrophyte areas along the day (CARNIATTO et al., 2012), independent of the lake area, sampling was conducted in open and macrophyte areas in the lakes only to better represent the fish assemblage of each lake (PETRY et al., 2003), and, therefore, the amount of food resources (herein food availability).

Collected fish were anesthetized, euthanized, identified, measured, eviscerated and their stomachs were preserved in $4 \%$ formaldehyde. Analysis of stomach contents was conducted under stereoscopic and compound microscopes and food items identified and quantified by the volumetric method (Hellawell \& Abel, 1971; Hyslop, 1980). Voucher specimens were deposited in the Nupélia Ichthyological Collection, Universidade Estadual de Maringá. For analysis, food items were grouped into nine broad taxonomic and/ or ecological categories, as follows: algae (ALG), detritus/ sediment (DET), aquatic insects (AQI), terrestrial insects (ITR), other aquatic invertebrates (OIA), other terrestrial invertebrates (OTI), microcrustaceans (MIC), fish (FIS), and plants (PLA).

The availability of food resources in the lakes was estimated from the total volume of the items found in all stomachs analyzed (LAWLOR, 1980; WINEMILLER, 1989; LuZ-AgostinHo et al., 2006; RöPKE et al., 2014). This method uses fish as samplers of their environment and it is more reliable because the fish assemblages are represented by larger amounts of functional groups, or guilds, as in the case of the Neotropical realm. It should be considered that this procedure results in an approximation of resource availability (LuZ-AgostinHo et al., 2006; RöPKE et al., 2014).

As all stomachs with food were not analyzed, the volumes of the items were corrected by the proportion of the species in a sample, considering only the individuals with food in their stomachs, according to the equation of LuZ-AgostinHo et al. (2006).

The food resource availability (here considered food consumed for all species) was summarized across the sampled lakes with a principal coordinate analysis ( $\mathrm{PCoA})$ applied on the food resource matrix. The PCoA is an ordination technique that represents any dissimilarity matrix as closer as possible to an Euclidean representation (LEGENDRE \& LEGENDRE, 1998). The Bray-Curtis distance was used to represent the distances of the food resources availability (variables) between the lakes (samples). The first two PCoA axes were retained for interpretation as they represent the greatest part of the variation on the distances between samples. Pearson correlations between each PCoA axis and the original variables (each availability in the food resource matrix) were performed to assess the association between each food resource and each PCoA axis.

The food selectivity of the species was evaluated for each lake, based on the availability of the items in the environment and the stomach contents for each species with more than three stomachs analyzed. This analysis was carried out using Ivlev's electivity Index (IvLEv, 1961), modified, which is defined as: $E=(r-D) /(r+D)$ where: $E=$ Index of 


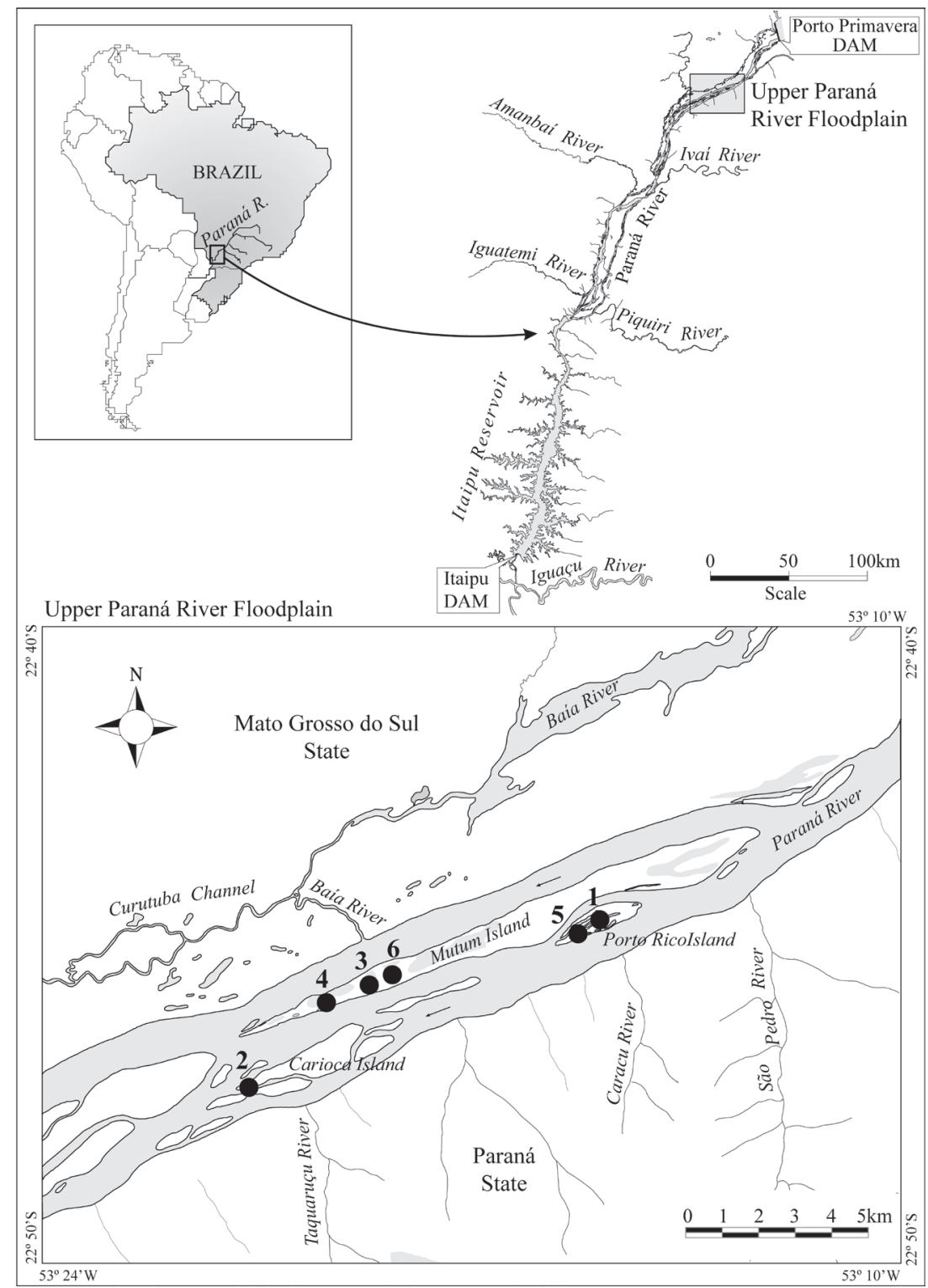

Fig. 1. Locations of the lakes on the upper Paraná River floodplain, Brazil: 1, Canal do Meio; 2, Carioca; 3, Zé Marinho; 4, Cidão; 5, Genipapo; 6, Tião.

electivity $r=$ relative volume of the items in the stomach contents; $D=$ food resource availability, obtained by total consumption of food resources in each lake by the fishes.

Values of $E$ can range from -1 to +1 , indicating complete avoidance or preference, respectively. Values close to zero indicate that the item was ingested in the same proportion between species. The relationship between the food availability and selectivity was evaluated by linear regression analyses and shape of data distribution (the latter using the program EcoSim; Gotelli \& ENSTMINGER, 2001). For this analysis, only values of $E$ greater than 0 were used and they were plotted against the availability of the food categories, for each floodplain lake separated.

To determine the feeding overlap among species (interspecific) the Schoener's Index of proportional similarity was used (SCHOENER, 1968). This Index varies from 0 to 1 , with a value of 1 indicating complete food overlap among the species. To assess if and how the variation in resource availability affects the feeding overlap among species (interspecific), it was calculated the mean Index of proportional similarity $(\mathrm{O})$ across all pairs of species by lake. Then Pearson correlations were done with the mean $\mathrm{O}$ by lake and the $\mathrm{PCoA}$ axes scores that summarized the food resource matrix (or resource availability). Although the data on the availability of resources for the lakes came from sampled fish, both $\mathrm{O}$ and PCoA scores showed stochastic independence (Hoeffding's D: PCOA 1: $\mathrm{D}=-0.17, \mathrm{p}=1.00$; PCOA 2: $-0.33, \mathrm{p}=1.00$ ).

To determine the feeding overlap among individuals of the same species (intraspecific) in each lake, the Schoener's Index of proportional similarity (SCHOENER, 1968), modified by BoLNICK et al. (2002) was used.

This Index varies from 0 to 1 , with a value of 1 indicating complete overlap among individuals, i.e., a value close to 1 indicate a less specialized individual, while close 
to 0 indicate a more specialized individual (BoLNICK et al., 2002). This analysis was performed using the items identified with lowest possible taxonomic level.

To assess if and how the variation in resource availability affects the feeding overlap among individuals, it was calculated the mean Index of proportional similarity (O) by each species by lake (IS; BoLNICK et al., 2002). Then Pearson correlations were calculated for the mean IS by lake and the PCoA axes scores that summarized the food resource matrix (resource availability). The stochastic independence of the data was assessed because the availability of food resource, for the lakes, came from the sampled individuals, both $\mathrm{O}$ and PCoA scores showed a low degree of stochastic dependence (Hoeffding's D: PCOA 1: D $=0.17, p=0.04$; PCOA 2: $-0.33, \mathrm{p}=1.00)$.

\section{RESULTS}

The ichthyofauna of the six floodplain lakes was composed of 33 species, belonging to six orders and 11 families. In general, species were small-sized (only six species with $L_{\mathrm{s}}>10 \mathrm{~cm}$ ) and abundance was highly variable. Most abundant species (individual. $\mathrm{m}^{-2}$ ) were Astyanax altiparanae Garutti \& Britski, 2000 (7.28 ind. m $^{-2}$ ), Aphyocharax anisitsi Eigenmann \& Kennedy, 1903 (4.48 ind. m $^{-2}$ ) and Moenkhausia sanctaefilomenae Steindachner, 1907 (3.05 ind. $\left.\mathrm{m}^{-2}\right)$. Species richness was higher in Genipapo (22) and Carioca lakes (18; Tab. I). During samplings, we captured 2,757 individuals. Of this total, 1,473 presented food in their stomachs and we analyzed 599 stomachs ( $40.7 \%$ of the total). For the analyzed stomachs, 73 came from Carioca Lake, 70 from Genipapo, 50 from Zé Marinho, 110 from Cidão, 160 from Tião and 137 from Canal do Meio (Tab. II).

The PCoA applied to the availability of food resource represented approximately $80.6 \%$ of the variability on the distances of resource availability among the lakes in the data matrix. The first axis was negatively correlated to the availability of plants. The second axis was positively correlated to the availability of terrestrial insects and other terrestrial invertebrates (Tab. III; Fig. 2).

Except for Astyanax altiparanae, which was recorded in four of the six lakes sampled, all species showed feeding preferences in one or more lakes. Feeding plasticity was also observed for Moenkhausia sanctaefilomenae, which showed important levels of selection for three of the five lakes in which it was captured (Carioca, Genipapo and Zé Marinho); this species generally took the most abundant food in the other floodplain lakes (Tab. IV).

The relationship between selectivity and the availability of food resources could not be determined by regression analysis because assumptions were not met. However, the shape of data distribution can be considered an envelope effect, which was tested for randomness. In fact, the shape showed a non-random distribution pattern (Fig. 3; observed dispersion $=30.92 ; P=0.048$ after 5000 randomizations; GoldberG \& SCheINER, 1993). The variability in the degree of selection/electivity was high in conditions of low food availability. In general, the degree of food selection was lower in conditions of high availability.

The values of the Schoener's Index $(\mathrm{O})$ for interspecific overlap were highly variable, not showing a pattern for the study lakes (Fig. 4). Values of $\mathrm{O}$ ranged from 0.133 to 0.376 (mean \pm S.D.: $0.259 \pm 0.090$ ) among all sampled lakes. Values of $\mathrm{O}$ were not correlated to the scores of the first nor to the second PCoA axis that summarized the food resource matrix (food availability; PCoA 1: $r=0.48, P=0.33, N=$ 6; PCoA 2: $r=-0.22, P=0.66, N=6$ ).

The mean intraspecific diet overlap by species (IS) varied from 0.313 to 0.939 (mean \pm S.D.: $0.674 \pm 0.164$ ) among all sampled lakes. The mean IS was positively correlated to the scores of the first PCoA axis of food resource availability (PCoA 1: $r=0.87, P=0.02, N=6$; PCoA 2: $r=0.33, P=$ $0.52, N=6$ ). The mean intraspecific diet overlap tended to increase as the availability of plants decreased and with higher availability of insects in the sampled lakes (Fig. 5).

\section{DISCUSSION}

Studies of feeding selectivity or those that use selectivity as an indicator of competition have great challenges to determine availability accurately (MATTHEWs, 1998), especially in evaluations of entire assemblages. The first difficulty is methodological, given that the categories of food resources (e.g., algae, insects, fish, and higher plants) require different sampling techniques that have distinct selectivity, and do not yield comparable results (GERKING, 1994). Moreover, the absolute abundance of an item in the environment is not directly related to its availability for consumption by fish (Wootton, 1999; Uieda \& Pinto, 2011). Therefore, in spite of the limitations imposed by the absence or scarcity of species of a particular trophic level in a given environment, the use of stomach content analysis of all the species present in a biotope still constitutes the most acceptable and practical alternative to allow inferences about the availability of resources (LuZ-AGOSTINHO et al., 2006; RÖPKE et al., 2014). Restrictions are greater when different environments are compared because they will present different faunal composition. Such inferences, nevertheless, assume that the group of species analyzed exploits all the possible resources that are present and available in the environment (WineMILLER \& Kelso-WineMILleR, 1996; LuZ-AgostinHO et al., 2006; MONTEIRO et al., 2009; RÖPKE et al., 2014).

In this study, we considered fish as samplers and this allowed us to determine resources availability. Based on this, we were able to find trends of low food selectivity, verified under condition of high availability of food resources. However, when food availability was low, selectivity was highly variable. The interspecific diet overlap presented high variability in the different values of food availability. This result did not support the second hypothesis; interspecific overlap was not correlated to resource availability in the study lakes. On the other hand, individuals become generalist and the intraspecific overlap was higher when food availability (insects) was higher. This result corroborates the first and the 
Tab. I. Range (Max = maximum; Min = minimum) of standard length $(\mathrm{Ls} ; \mathrm{cm})$ and abundance (individuals. $\mathrm{m}^{-2}$ ) of the species captured in the study lakes (CA, Carioca; GE, Genipapo; ZM, Zé Marinho; CI, Cidão; TI, Tião; CM, Canal do Meio). †, values below 0.005

\begin{tabular}{|c|c|c|c|c|c|c|c|c|}
\hline \multirow{2}{*}{ Species } & \multirow{2}{*}{$\begin{array}{c}\text { Ls } \\
\text { Max-Min }\end{array}$} & \multicolumn{7}{|c|}{ Abundance } \\
\hline & & $\mathrm{CA}$ & GE & $\mathrm{ZM}$ & $\mathrm{CI}$ & TI & $\mathrm{CM}$ & Total \\
\hline \multicolumn{9}{|l|}{ Characiformes } \\
\hline Astyanax altiparanae Garutti \& Britski, 2000 & $8.0-1.7$ & 1.08 & 0.62 & 0.23 & 4.21 & 1.14 & $\dagger$ & 7.28 \\
\hline Aphyocharax anisitsi Eigenmann \& Kennedy, 1903 & $3.7-1.1$ & & 0.07 & 0.04 & 0.02 & 0.29 & 4.06 & 4.48 \\
\hline Cyphocharax modestus (Fernández-Yépez, 1948) & $4.3-4.2$ & 0.02 & & & & & & 0.02 \\
\hline Erythrinus erythrinus (Bloch \& Schneider, 1801) & $14.0-8.2$ & 0.01 & & & 0.01 & & & 0.02 \\
\hline Hemigrammus marginatus Ellis, 1911 & $3.5-2.7$ & & 0.11 & 0.06 & & & & 0.17 \\
\hline Hyphessobrycon eques (Steindachner, 1882) & $3.5-0.9$ & & & 0.01 & & & 0.53 & 0.54 \\
\hline Hoplias aff. malabaricus (Bloch, 1794) & $5.8-1.8$ & & 0.02 & & & $\dagger$ & 0.05 & 0.07 \\
\hline Hoplerythrinus unitaeniatus (Agassiz, 1829) & $15.7-13.5$ & 0.02 & & & & & & 0.02 \\
\hline Moenkhausia intermedia Eigenmann, 1908 & $3.4-1.6$ & 0.01 & 0.16 & & & & & 0.17 \\
\hline Moenkhausia sanctaefilomenae (Steindachner, 1907) & $3.9-0.9$ & 0.11 & 1.22 & 0.04 & 0.56 & 1.12 & & 3.05 \\
\hline Pyrrhulina australis Eigenmann \& Kennedy, 1903 & $3.0-1.6$ & 0.22 & 0.04 & & & & & 0.26 \\
\hline Roeboides descalvadensis Fowler, 1932 & $5.5-1.7$ & 0.09 & 0.21 & 0.03 & & & & 0.33 \\
\hline Serrasalmus marginatus Valenciennes, 1837 & $3.8-2.2$ & 0.01 & 0.07 & & & & & 0.08 \\
\hline Serrapinnus notomelas (Eigenmann, 1915) & $3.6-1.2$ & & 0.08 & 0.01 & & 0.08 & 0.97 & 1.14 \\
\hline Serrapinus sp.1 & 1.4 & & & & & 0.02 & & 0.02 \\
\hline Steindachnerina brevipinna (Eigenmann \& Eigenmann, 1889) & $5.6-1.5$ & 0.56 & 0.85 & & 0.07 & 0.08 & & 1.56 \\
\hline Steindachner insculpta (Fernández-Yépez, 1948) & $3.4-1.5$ & & 0.12 & & & & & 0.12 \\
\hline \multicolumn{9}{|l|}{ Perciformes } \\
\hline Astronotus crassipinnis (Heckel, 1840) & $9.0-7.8$ & & 0.04 & & & & & 0.04 \\
\hline Cichlasoma paranaense Kullander, 1983 & $8.3-1.3$ & 0.21 & 0.11 & & & 0.04 & 0.05 & 0.41 \\
\hline Crenicichla britskii Kullander, 1982 & 8.6 & & 0.02 & & & & & 0.02 \\
\hline Crenicichla niederleinii (Holmberg, 1891) & 2.3 & & & & & & 0.01 & 0.01 \\
\hline Cichla kelberi Kullander \& Ferreira, 2006 & 15.6 & & 0.02 & & & & & 0.02 \\
\hline Satanoperca pappaterra (Heckel, 1840) & $6.8-5.4$ & & 0.02 & 0.01 & & & & 0.03 \\
\hline Laetacara sp. & $4.8-1.0$ & 0.12 & & 0.36 & & 0.01 & 2.12 & 2.61 \\
\hline \multicolumn{9}{|l|}{ Siluriformes } \\
\hline Hoplosternum littorale (Hancock, 1828) & $10.8-0.8$ & 0.04 & 0.03 & & 0.03 & 0.06 & 0.08 & 0.24 \\
\hline Pterygoplichthys ambrosettii (Holmberg, 1893) & $11.3-1.2$ & & 0.05 & 0.03 & & & & 0.08 \\
\hline Pimelodella sp.1 & 2.1 & & 0.01 & & & & & 0.01 \\
\hline Loricariichthys platymetopon Isbrücker \& Nijssen, 1979 & $15.1-7.3$ & & 0.08 & & & & $\dagger$ & 0.08 \\
\hline \multicolumn{9}{|l|}{ Gymnotiformes } \\
\hline Eigenmannia trilineata López \& Castello, 1966 & $9.3-5.1$ & 0.01 & 0.02 & & & & & 0.03 \\
\hline Gymnotus sp. & 17.7 & 0.13 & & & & & 0.01 & 0.14 \\
\hline \multicolumn{9}{|l|}{ Cyprinodontiformes } \\
\hline Poecilia reticulata Peters, 1859 & $2.1-1.4$ & 0.04 & & & & & & 0.04 \\
\hline Melanorivulus apiamici (Costa, 1989) & $2.4-1.3$ & 0.17 & & & & & & 0.17 \\
\hline \multicolumn{9}{|l|}{ Synbranchiformes } \\
\hline Synbranchus marmoratus Bloch, 1795 & $48.2-7.8$ & 0.03 & & & & 0.01 & 0.13 & 0.17 \\
\hline Number of species & & 18 & 22 & 10 & 6 & 11 & 12 & 33 \\
\hline
\end{tabular}

Tab. II. Food resources identified for each species at the six isolated lakes of the upper Paraná River floodplain. $\mathrm{N}=$ total number of species caught, $\mathrm{n}$ = number of stomachs analyzed (ALG, Algae; DET, Detritus/sediment; AQI, Aquatic insects; ITR, Terrestrial insects; OAI, Other aquatic invertebrates; OTI, Other terrestrial invertebrates; MIC, Microcrustaceans; FIS, Fish; PLA, Plants).

\begin{tabular}{|c|c|c|c|c|c|c|c|c|c|c|c|}
\hline \multirow{2}{*}{ Lakes/species } & \multirow{2}{*}{$\mathrm{N}$} & \multirow{2}{*}{$\mathrm{n}$} & \multicolumn{9}{|c|}{ Food resources (\% Volume) } \\
\hline & & & ALG & DET & AQI & ITR & OAI & OTI & $\mathrm{MIC}$ & FIS & PLA \\
\hline \multicolumn{12}{|l|}{ Carioca } \\
\hline Astyanax altiparanae & 116 & 20 & 6.46 & 9.33 & 2.66 & 26.04 & 0.96 & & 0.07 & & 54.47 \\
\hline Moenkhausia intermedia & 1 & 1 & 56.37 & 22.41 & 18.87 & & 2.36 & & & & \\
\hline Moenkhausia sanctaefilomenae & 12 & 3 & 14.16 & 24.99 & & 22.72 & 2.53 & & 1.51 & & 34.08 \\
\hline Erythrinus erythrinus & 2 & 1 & & & 57.92 & & 3.47 & 38.61 & & & \\
\hline Eigenmannia trilineata & 1 & 1 & & & 99.59 & & & & 0.41 & & \\
\hline Gymnotus spp. & 19 & 8 & 0.07 & & 90.19 & 1.76 & 0.46 & & 7.52 & & \\
\hline Cichlasoma paranaense & 30 & 2 & 7.69 & 30.77 & 23.08 & 38.46 & & & & & \\
\hline Pyrrhulina australis & 32 & 8 & 1.25 & & 54.55 & 28.21 & 1.25 & 6.27 & 8.46 & & \\
\hline
\end{tabular}


Tab. II. Cont.

\begin{tabular}{|c|c|c|c|c|c|c|c|c|c|c|c|}
\hline \multirow{2}{*}{ Lakes/species } & \multirow{2}{*}{$\mathrm{N}$} & \multirow{2}{*}{$\mathrm{n}$} & \multicolumn{9}{|c|}{ Food resources (\% Volume) } \\
\hline & & & ALG & DET & AQI & ITR & OAI & OTI & MIC & FIS & PLA \\
\hline Roeboides descalvadensis & 10 & 7 & 1.68 & 11.49 & 78.02 & 6.29 & 2.52 & & & & \\
\hline Melanorivulus apiamici & 26 & 3 & & & 43.48 & 34.78 & & & 21.74 & & \\
\hline Hoplosternum littorale & 4 & 4 & 5.61 & 50.36 & 5.54 & 11.40 & 3.91 & & 23.17 & & \\
\hline Synbranchus marmoratus & 4 & 1 & & & 38.27 & 1.33 & 26.55 & & & 22.12 & 11.73 \\
\hline Cyphocharax modestus & 2 & 1 & 10.80 & 85.40 & & & 3.80 & & & & \\
\hline Steindachnerina brevipinna & 61 & 11 & 10.91 & 84.50 & & & 4.59 & & & & \\
\hline Laetacara sp. & 18 & 1 & & & 23.08 & & 7.69 & & 69.23 & & \\
\hline Serrasalmus marginatus & 1 & 1 & & & & & & & & 100 & \\
\hline \multicolumn{12}{|l|}{ Genipapo } \\
\hline Astyanax altiparanae & 33 & 12 & & & 31.85 & 61.93 & & 4.66 & & $0.44 *$ & 1.11 \\
\hline Moenkhausia sanctaefilomenae & 73 & 19 & & & 42.66 & 23.26 & & & 0.19 & & 33.90 \\
\hline Pyrrhulina australis & 3 & 1 & & & 100 & & & & & & \\
\hline Roeboides descalvadensis & 11 & 6 & & & 85.59 & & & 14.41 & & & \\
\hline Eigenmannia trilineata & 1 & 1 & & & 50.00 & & & & 50.00 & & \\
\hline Aphyocharax anisitsi & 5 & 2 & & & 60.00 & & & & 40.00 & & \\
\hline Moenkhausia intermedia & 8 & 2 & 9.62 & 30.73 & 41.42 & & 2.67 & & 15.56 & & \\
\hline Hoplias malabaricus & 1 & 1 & & & & & 100 & & & & \\
\hline Loricariichthys platymetopon & 4 & 4 & 19.10 & 76.29 & & & 4.62 & & & & \\
\hline Pterygoplichthys ambrosettii & 3 & 1 & 9.83 & 90.04 & & & 0.13 & & & & \\
\hline Steindachnerina brevipinna & 44 & 11 & 33.04 & 63.41 & & & 3.55 & & & & \\
\hline Steindachnerina insculpta & 6 & 3 & 33.54 & 56.34 & & & 10.12 & & & & \\
\hline Hoplosternum littorale & 2 & 1 & & & & & & & 100 & & \\
\hline Cichlasoma paranaense & 7 & 2 & & & & 1.01 & & & & 98.99 & \\
\hline Serrasalmus marginatus & 4 & 3 & & & & & & & & 100 & \\
\hline Astronotus crassipinnis & 2 & 1 & 7.80 & & & & 0.46 & & & & 91.74 \\
\hline \multicolumn{12}{|l|}{ Zé Marinho } \\
\hline Astyanax altiparanae & 31 & 22 & 0.65 & & 3.44 & 6.18 & 13.10 & & 1.36 & $0.84 *$ & 74.43 \\
\hline Serrapinnus notomelas & 2 & 1 & 3.33 & & & & & & 13.33 & & 83.33 \\
\hline Hemigrammus marginatus & 8 & 2 & & & & & & & 91.80 & $8.20^{*}$ & \\
\hline Aphyocharax anisitsi & 7 & 3 & & & 38.24 & & & & 61.76 & & \\
\hline Laetacara sp. & 68 & 12 & 0.71 & & 8.50 & 19.26 & 69.41 & & 0.71 & $1.42 *$ & \\
\hline Moenkhausia sanctaefilomenae & 8 & 5 & 1.54 & & 27.16 & 36.42 & & 9.26 & & & 25.62 \\
\hline Roeboides paranensis & 4 & 2 & & & 49.33 & 30.67 & & & & $20.0^{*}$ & \\
\hline Pterygoplichthys ambrosettii & 6 & 3 & 22.96 & 76.80 & & & 0.25 & & & & \\
\hline \multicolumn{12}{|l|}{ Cidão } \\
\hline Astyanax altiparanae & 187 & 48 & 0.02 & 0.15 & 60.17 & 6.87 & 0.13 & 2.87 & 3.89 & $1.25^{*}$ & 24.65 \\
\hline Erythrinus erythrinus & 4 & 1 & & & 52.94 & 3.49 & 26.14 & 17.43 & & & \\
\hline Moenkhausia sanctaefilomenae & 109 & 58 & 0.01 & 0.26 & 77.73 & 3.20 & 0.12 & 0.54 & 7.80 & $0.05^{*}$ & 10.29 \\
\hline Hoplosternum littorale & 3 & 1 & & & 26.67 & & & & 73.33 & & \\
\hline Steindachnerina brevipinna & 4 & 2 & 38.91 & 61.09 & & & & & & & \\
\hline \multicolumn{12}{|l|}{ Tião } \\
\hline Astyanax altiparanae & 215 & 68 & 0.22 & & 29.07 & 12.04 & 0.34 & 1.60 & 12.11 & $0.42 *$ & 44.19 \\
\hline Aphyocharax anisitsi & 19 & 7 & 0.02 & & 29.47 & & 0.18 & & 66.69 & & 3.64 \\
\hline Steindachnerina brevipinna & 7 & 4 & 4.00 & 95.85 & & & 0.15 & & & & \\
\hline Hoplosternum littorale & 3 & 1 & 4.36 & & & 20.56 & 0.48 & & 48.23 & & 26.37 \\
\hline Hoplias aff. malabaricus & 2 & 2 & & & 100 & & & & & & \\
\hline Laetacara sp. & 6 & 1 & & & 100 & & & & & & \\
\hline Moenkhausia sanctaefilomenae & 206 & 75 & 0.04 & & 53.61 & 18.18 & 0.64 & 0.49 & 6.80 & $0.04 *$ & 20.20 \\
\hline Synbranchus marmoratus & 4 & 2 & & & 37.74 & 58.18 & 3.30 & & & & 0.79 \\
\hline \multicolumn{12}{|l|}{ Canal do Meio } \\
\hline Astyanax altiparanae & 1 & 1 & 99.90 & & & & 0.10 & & & & \\
\hline Crenicichla niederleinii & 1 & 1 & 64.29 & & & & & & & & 35.71 \\
\hline Laetacara sp. & 319 & 5 & 40.49 & & 10.71 & & 10.39 & & 16.37 & & 22.04 \\
\hline Gymnotus spp. & 2 & 1 & & & 98.94 & & & & 1.06 & & \\
\hline Hyphessobrycon eques & 81 & 1 & & & 100 & & & & & & \\
\hline Synbranchus marmoratus & 19 & 18 & & & 97.90 & 0.57 & 1.52 & & & & \\
\hline
\end{tabular}


Tab. II. Cont.

\begin{tabular}{|c|c|c|c|c|c|c|c|c|c|c|c|}
\hline \multirow{2}{*}{ Lakes/species } & \multirow{2}{*}{$\mathrm{N}$} & \multirow{2}{*}{$\mathrm{n}$} & \multicolumn{9}{|c|}{ Food resources (\% Volume) } \\
\hline & & & ALG & DET & AQI & ITR & OAI & OTI & MIC & FIS & PLA \\
\hline Hoplias aff. malabaricus & 8 & 2 & & & 1.72 & & & & & 98.28 & \\
\hline Loricariichthys platymetopon & 1 & 1 & 8.91 & 65.32 & & & 0.36 & & 25.42 & & \\
\hline Hoplosternum littorale & 15 & 5 & 32.18 & 5.09 & & & 18.52 & & 21.30 & $22.9^{*}$ & \\
\hline Serrapinnus notomelas & 177 & 30 & 49.21 & 0.76 & 2.78 & & 41.35 & & 5.90 & & \\
\hline Aphyocharax anisitsi & 684 & 72 & 9.83 & 0.43 & 40.84 & & 36.47 & & 12.21 & & 0.21 \\
\hline
\end{tabular}

third predictions tested; species become less selective with higher availability of food resources and the intraspecific overlap was higher when the food resources availability was high (particularly the availability of aquatic insects).

There are studies demonstrating that some species of tropical fishes show a certain degree of feeding preference, but selectivity is considered low at these latitudes, with the majority of species showing a high degree of plasticity in their diets (ABELHA et al., 2001; RoNDINELli et al., 2011; UIEDA \& PINTO, 2011). In the study lakes, the degree of selectivity was generally low for A. altiparanae and $M$. sanctaefilomenae, which altered their diet according to the most abundant resource in each lake, alternating their diet among insectivory, herbivory and omnivory. The dietary plasticity of these species, which is common for the majority of characids (ABELHA et al., 2001; DiAs et al., 2005; UIEDA \& PINTO, 2011), may likely explain their greater abundance and wider distribution in the lakes.

Among the species with greater feeding selectivity, the detritivores A. anisitsi, Steindachnerina insculpta (FernándezYépez, 1948), Loricariichthys platymetopon (Isbrücker \& Nijssen, 1979) and Steindachnerina brevipinna (Eigenmann \& Eigenmann, 1889) were prominent. In addition to detritus, these species ingested algae and other non-insect aquatic invertebrates. The selection of detritus by these species was expected, independent of its availability in the lakes, mainly because of the foraging behavior, morphology of their digestive tracts, physiological traits as well as by phylogeny (Bowen, 1983; Fugi et al., 1996; LuJAN et al., 2011; DAVIS et al., 2013; CORREA \& WinemiLler, 2014), are factors that limit the use of other items.

Among the insectivores, which generally showed less selectivity, selection was important for Synbranchus marmoratus (Bloch, 1795) and Melanorivulus apiamici (Costa, 1989); the latter species consumed important amounts of microcrustaceans, which had low availability in the lake where it occurred (Carioca). In floodplains, which typically have wide seasonal variations in the limnological characteristics of the water bodies that remain after the water retreats, it is expected that the species will show low food selectivity and will take the food that is most abundant in a given season (LuZ-AGOSTINHO et al., 2006, 2008; RÖPKE et al., 2014; Pereira et al., 2017). However, in the three years preceding the sampling for the present study, the flood regime was controlled by upstream reservoirs, especially Porto Primavera (completed in December 1998). During this period, only Carioca Lake, and to a lesser extent Genipapo Lake, became connected to the main river channel; whereas the
Tab. III. Principal coordinate analysis (PCoA) that summarized the food resource matrix (food availability) of the sampled lakes. It is presented the Pearson correlations of the scores of each axis with the original variables, the eigenvalue and the percentage of explanation of each axis. Variables with significant Pearson correlations are in bold.

\begin{tabular}{lcc}
\hline Variable & PCoA 1 & PCoA 2 \\
\hline ALG & 0.343 & -0.458 \\
PLA & $\mathbf{- 0 . 9 4 6}$ & -0.031 \\
AQI & $\mathbf{0 . 8 5 7}$ & 0.015 \\
ITR & -0.007 & $\mathbf{0 . 8 4 2}$ \\
OAI & -0.073 & $\mathbf{- 0 . 8 7 2}$ \\
OTI & 0.297 & $\mathbf{0 . 9 4 4}$ \\
MIC & 0.540 & -0.590 \\
FIS & -0.169 & 0.636 \\
DET & -0.234 & 0.673 \\
Eigenvalue & 0.351 & 0.247 \\
Percent of explanation & 44.32 & 33.28 \\
\hline
\end{tabular}

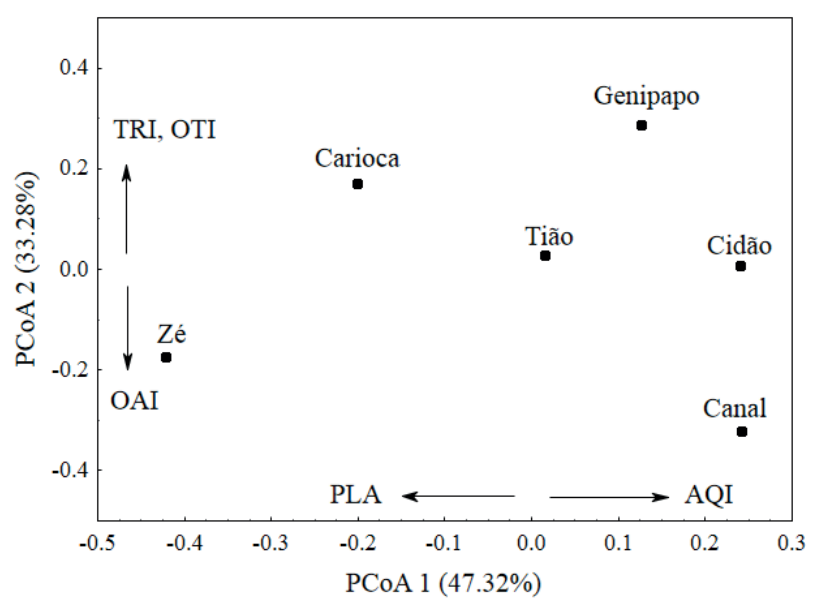

Fig. 2. Ordination by principal coordinate analysis (PCoA) of the food resource availability for six floodplain lakes along the Upper Paraná River, Paraná-Mato Grosso do Sul. AQI = aquatic insects; OAI = other aquatic invertebrates; OTI = other terrestrial invertebrates; PLA = plants; TRI = terrestrial insects.

variations in water level of the other lakes resulted essentially from changes in the water table.

The general pattern obtained for the relationship between food selectivity and availability among the species revealed the existence of the envelope effect (GOLDBERG \& SCHEINER, 1993). It was clear however, that under conditions of scarce resources, the degree of selection varied widely; whereas selection was less pronounced in situations of high availability. This pattern, which the dispersion test showed to be non-random, demonstrated that other factors [i.e., 
Tab. IV. Food selection of the ichthyofauna and availability of resources in six floodplain lakes of the upper Paraná River (ALG, Algae; PLA, Higher plants; AQI, Aquatic insects; ITR, Terrestrial insects; OAI, Other aquatic invertebrates; OTI, Other terrestrial invertebrates; MIC, Microcrustaceans; FIS, Fish; DET, Detritus/sediment).

\begin{tabular}{|c|c|c|c|c|c|c|c|c|c|}
\hline Lake/Food resources & ALG & PLA & AQI & ITR & OAI & OTI & MIC & FIS & DET \\
\hline \multicolumn{10}{|l|}{ Carioca } \\
\hline Astyanax altiparanae & 0.10 & 0.27 & -0.75 & 0.23 & -0.61 & -1 & -0.94 & -1 & -0.32 \\
\hline Gymnotus sp. & -0.97 & -1 & 0.65 & -0.81 & -0.80 & -1 & 0.55 & -1 & -1 \\
\hline Pyrrhulina australis & -0.62 & -1 & 0.49 & 0.26 & -0.52 & 0.60 & 0.59 & -1 & -1 \\
\hline Roeboides descalvadensis & -0.52 & -1 & 0.61 & -0.45 & -0.23 & -1 & -1 & -1 & -0.22 \\
\hline Steindachnerina brevipinna & 0.34 & -1 & -1 & -1 & 0.07 & -1 & -1 & -1 & 0.65 \\
\hline Hoplosternum littorale & 0.03 & -1 & -0.54 & -0.18 & -0.01 & -1 & 0.83 & -1 & 0.47 \\
\hline Moenkhausia sanctaefilomenae & 0.45 & 0.04 & -1 & 0.16 & -0.23 & -1 & -0.18 & -1 & 0.16 \\
\hline Melanorivulus apiamici & -1 & -1 & 0.40 & 0.36 & -1 & -1 & 0.82 & -1 & -1 \\
\hline Availability & 5.34 & 36.41 & 18.8 & 16.46 & 4.01 & 1.58 & 2.16 & 2.29 & 12.93 \\
\hline \multicolumn{10}{|l|}{ Genipapo } \\
\hline Astyanax altiparanae & -1 & -0.81 & 0.01 & 0.19 & -1 & 0.26 & -1 & -0.71 & -1 \\
\hline Moenkhausia sanctaefilomenae & -1 & 0.52 & 0.15 & -0.29 & -1 & -1 & 0.19 & -1 & -1 \\
\hline Roeboides descalvadensis & -1 & -1 & 0.46 & -1 & -1 & 0.68 & -1 & -1 & -1 \\
\hline Steindachnerina brevipinna & 0.82 & -1 & -1 & -1 & 0.75 & -1 & -1 & -1 & 0.81 \\
\hline Loricariichthys platymetopon & 0.70 & -1 & -1 & -1 & 0.80 & -1 & -1 & -1 & 0.84 \\
\hline Steindachnerina insculpta & 0.82 & -1 & -1 & -1 & 0.91 & -1 & -1 & -1 & 0.79 \\
\hline Serrasalmus marginatus & -1 & -1 & -1 & -1 & -1 & -1 & -1 & 0.95 & -1 \\
\hline Availability & 3.31 & 10.73 & 31.39 & 42.00 & 0.50 & 2.73 & 0.13 & 2.60 & 6.62 \\
\hline \multicolumn{10}{|l|}{ Zé Marinho } \\
\hline Astyanax altiparanae & -0.03 & 0.08 & -0.14 & -0.15 & -0.23 & -1 & 0 & -0.11 & -1 \\
\hline Laetacara $\mathrm{sp}$. & 0.02 & -1 & 0.30 & 0.40 & 0.54 & -1 & -0.31 & 0.16 & -1 \\
\hline Aphyocharax anisitsi & -1 & -1 & 0.79 & -1 & -1 & -1 & 0.96 & -1 & -1 \\
\hline Pterygoplichthys ambrosettii & 0.94 & -1 & -1.00 & -1 & -0.98 & -1 & -1 & -1 & 1 \\
\hline Moenkhausia sanctaefilomenae & 0.39 & -0.42 & 0.71 & 0.63 & -1 & 0.99 & -1 & -1 & -1 \\
\hline Availability & 0.69 & 63.02 & 4.57 & 8.32 & 20.88 & 0.05 & 1.35 & 1.04 & 0.09 \\
\hline \multicolumn{10}{|l|}{ Cidão } \\
\hline Astyanax altiparanae & -0.09 & 0.21 & -0.08 & 0.19 & -0.39 & 0.28 & -0.22 & 0.40 & -0.23 \\
\hline Moenkhausia sanctaefilomenae & -0.45 & -0.22 & 0.05 & -0.19 & -0.43 & -0.50 & 0.12 & -0.84 & 0.06 \\
\hline Steindachnerina brevipinna & 1 & -1 & -1 & -1 & -1 & -1 & -1 & -1 & 0.99 \\
\hline Availability & 0.03 & 16.08 & 70.36 & 4.70 & 0.30 & 1.61 & 6.15 & 0.54 & 0.23 \\
\hline \multicolumn{10}{|l|}{ Tião } \\
\hline Astyanax altiparanae & 0.22 & 0.14 & -0.16 & -0.10 & -0.17 & 0.18 & 0.11 & 0.25 & -1 \\
\hline Aphyocharax anisitsi & -0.73 & -0.80 & -0.15 & -1 & -0.46 & -1 & 0.74 & -1 & -1 \\
\hline Moenkhausia sanctaefilomenae & -0.58 & -0.25 & 0.15 & 0.10 & 0.14 & -0.39 & -0.18 & -0.70 & -1 \\
\hline Steindachnerina brevipinna & 0.93 & -1 & -1 & -1 & -0.52 & -1 & -1 & -1 & 1 \\
\hline Availability & 0.14 & 33.49 & 39.9 & 14.85 & 0.48 & 1.11 & 9.77 & 0.25 & 0.01 \\
\hline \multicolumn{10}{|l|}{ Canal do Meio } \\
\hline Aphyocharax anisitsi & -0.17 & -0.50 & 0.01 & -1 & 0.04 & - & 0.06 & -1 & -0.01 \\
\hline Hoplosternum littorale & 0.40 & -1 & -1 & -1 & -0.29 & - & 0.33 & 0.92 & 0.84 \\
\hline Laetacara $\mathrm{sp}$. & 0.49 & 0.94 & -0.58 & -1 & -0.53 & - & 0.21 & -1 & -1 \\
\hline Synbranchus marmoratus & -1 & -1 & 0.42 & 0.88 & -0.91 & - & -1 & -1 & -1 \\
\hline Serrapinnus notomelas & 0.56 & -1 & -0.87 & -1 & 0.10 & - & -0.29 & -1 & 0.27 \\
\hline Availability & 13.80 & 0.73 & 39.79 & 0.04 & 33.6 & 0 & 10.78 & 0.92 & 0.34 \\
\hline
\end{tabular}

opportunistic use of resources that are not regularly eaten under condition of high availability (MARTIN \& PFENNIG, 2010)] could likely explain the food selection response of the species analyzed, when food availability is low. In this way, UIEDA \& PINTo (2011), studying the ichthyofauna of a tropical stream, observed three scenarios of high-positive selectivity towards aquatic insects. First, fish presented preference for a very abundant item in the environment and consumed it in high proportions. This was the case for all species analyzed by the authors. Second, the preference for an item not so readily available in the environment, but consumed in high proportions. Finally the preference for an item not very abundant in the environment but consumed in low proportions.

Interspecific food overlap is a common occurrence in fish communities (Ross, 1986; CoRrea \& WiNEMILLER, 2014), even for those species which resource partitioning is important (Gerking, 1994; Olson et al., 2015). The absence of correlation between interspecific diet overlap and resource availability suggests that resource partitioning 
rather than resource segregation may be occurring in the diet of the fish assemblages of these floodplain lakes. CORREA \& WiNEMILLER (2014) found that changes in availability of preferred foods reduced interspecific niche overlap and this fact may be a mechanism that facilities the coexistence in species rich systems.

On the other hand, MATTHEWs (1998) and CORRÊA et al. (2011) stated that when a resource is scarce, species could converge toward an almost identical use of the resource, and thus a high degree of overlap would occur. These conditions can have implications for competition for food resources (PUSEY et al., 1995), which when it occurs tends to segregate species and reduces overlap. This was emphasized by ZARET \& RAND (1971), who stated that segregation in the utilization of foods and the subsequent reduction in overlap are more effective forces in conditions of scarcity. In addition, CORREA \& WINEMILLER (2014) and FIGUEIREDO et al. (2015) considered that resource partitioning is a direct consequence of interspecific competition for limited resources. However, feeding segregation among species requires some time. In the present case, the short temporal scale of the trophic dynamic and the nature of the environmental variations to which the fish assemblages are naturally subjected could be taken into account.

Samples were obtained at a single time and during a period when, in spite of the low connectivity with the river channel because of regulation by upstream impoundments, the water table began to fall. This resulted in a progressive reduction of the aquatic area, an increase in population density, and a reduction in resources, which in theory would lead to intensification of intra- and interspecific competitive pressures (GASPAR DA LuZ \& OKADA, 1999; Mateus $e t$ al., 2016), but without sufficient time for fish to develop meaningful segregation of resources. Also, the species that coexist in nature can segregate their use of resources along many dimensions, such as time and various aspects of the habitat (Hutchinson, 1957; McPeek, 2014). This condition allows ecologically similar species to coexist, and can reduces competition among them (SCHOENER, 1974; CoRreA \& WiNEMILLER, 2014; OLSON et al., 2015). Habitat structure and the daily activities of the species as important factors in determining interspecific interactions may also be considered (Gelós et al., 2010; CARNiatTo et al., 2012; AlmeIDA-Silva et al., 2015); these aspects were not evaluated in this study.

As it is expected that individuals of the same species have similar ecological requirements, it is also expected that the values of feeding overlap between them will be higher, compared to those of interspecific overlap (ARAúJo et al., 2008; MCPeEK, 2014). In the present study, however, the mean values of intraspecific feeding overlap for the different floodplain lakes were generally low, and some of these means were, paradoxically, equal or even lower than those for interspecies overlap (e.g., Tião and Canal do Meio lakes). The only lake in which the values of the former much exceeded those of the latter was Zé Marinho, where food availability was high and the density of fish was relatively low. These trends can be related with the high feeding plasticity that characterizes the Neotropical fish fauna (LOWE-McConNELL,

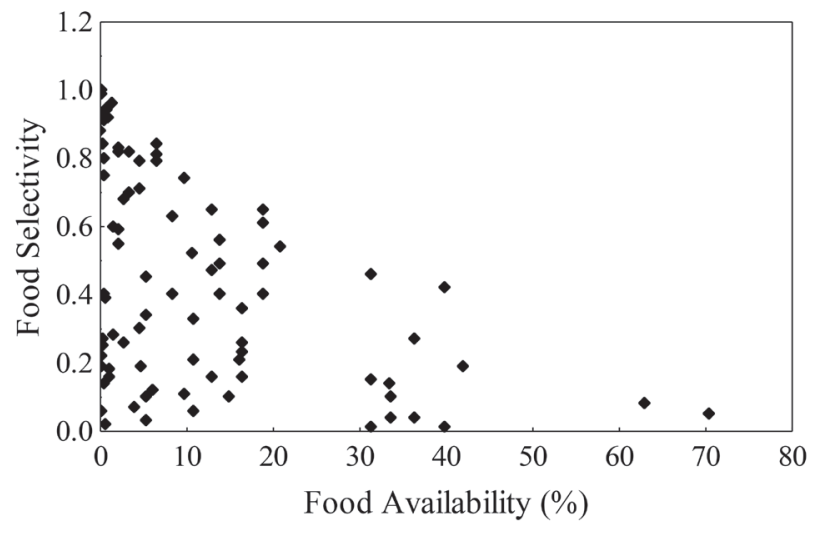

Fig. 3. Relationships between feeding selectivity by fish and the availability of food resources for six floodplain lakes along the Upper Paraná River, ParanáMato Grosso do Sul. Shape of data distribution (envelope effect) was significant.

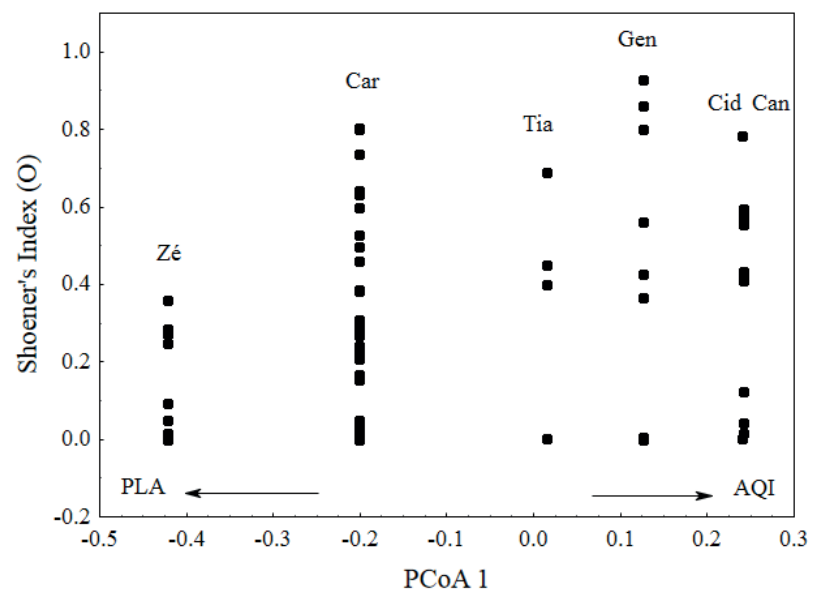

Fig. 4. Relationship of the mean the Schoener's Index (O) between pairs of species and the scores of the first PCoA axis of resource availability in isolated floodplain lakes along the upper Paraná River. The mean $\mathrm{O}$ was calculated based on 10 (Zé = Zé Marinho), $28($ Carioca $=$ Car $), 6($ Tião = Tia $), 21($ Genipapo $=$ Gen $), 3($ Cidão $=$ Cid $)$ and $10($ Canal $=$ Can $)$ pairs of species. $\mathrm{AQI}=$ aquatic insects; PLA = plants.

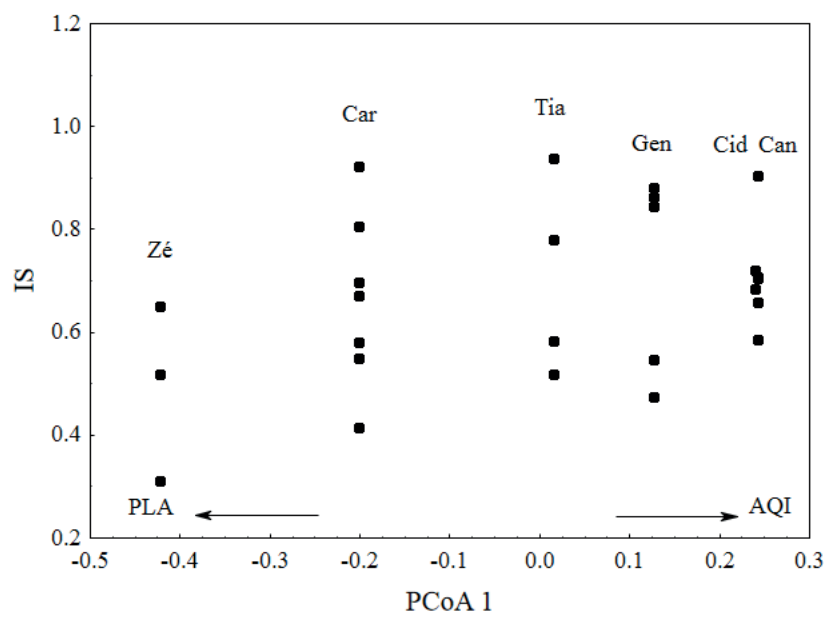

Fig. 5. Relationship between the mean of the proportional overlap Index (IS) and the scores of the first PCoA axis of resource availability in isolated floodplain lakes along the upper Paraná River.Values of IS closer to 1 indicates greater diet overlap. The mean IS was calculated based on individuals of 3 (Zé $=$ Zé Marinho), $7($ Carioca $=$ Car), 4 (Tião = Tia), $5($ Genipapo $=$ Gen), 2 (Cidão $=\mathrm{Cid})$ and 5 species $(\mathrm{Canal}=\mathrm{Can}) . \mathrm{AQI}=$ aquatic insects; $\mathrm{PLA}=$ plants. 
1987; ABELHA et al., 2001; RÖPKE et al., 2014). Analysis of the relationship between the mean values of the intraspecific Index of feeding overlap and the food resource availability showed that overlap tended to increase as availability of aquatic insects increased and the plants availability decreased.

In summary, considering the hypotheses tested, we can conclude that species become less selective when the environment provided higher availability of food resources. Interspecific overlap did not show a clear relationship with the availability of food resources in the lakes. However, intraspecific overlap tended to be more accentuated in conditions of high availability of food resources. In addition, species with low selectivity and the ones that showed accentuated partitioning of resources were more abundant and widely distributed on the study lakes.

Acknowledgments. The authors are grateful to N. S. Hahn and R. Fugi for reviewing and discussions the manuscript. To CNPq-PELD for fellowships and financial support, and to the Núcleo de Pesquisas em Limnologia, Ictiologia e Aqüicultura of the Universidade Estadual de Maringá and its field staff members for their help during sampling. AAA and LCG are researchers "Bolsa Produtividade" of CNPq.

\section{REFERENCES}

Abelha, M. C. F.; Agostinho, A. A. \& Goulart, E. 2001. Plasticidade trófica em peixes de água doce. Acta Scientiarum 23:425-434.

Almeida-Silva, P. H.; Tubino, R. A.; Zambrano, L. C.; Hunder, D. A.; Garritano, S. R. \& Monteiro-Neto, C. 2015. Trophic ecology and food consumption of fishes in a hypersaline tropical lagoon. Journal of Fish Biology 86:1781-1795.

AraúJo, M. S.; Bolnick, D. I. \& LaYman, C. A. 2011. The ecological causes of individual specialisation. Ecology Letters 14:948-958.

Araújo, M. S.; Guimarães JR., P. R.; Svanbäck, R.; Pinheiro, A.; Guimarães P.; Reis, S. F. \& Bolnick, D. 2008. Network analysis reveals contrasting effects of intraspecific competition on individual vs. population diets. Ecology 89:1981-1993.

Binzer, A.; Guill, C.; Rall, B. C. \& Brose, U. 2015. Interactive effects of warming, eutrofhication and size structure: impacts on biodiversity and food-web structure. Global Change Biology 22:220-227.

Bolnick, D. I.; Ingram, T.; Stutz, W. E.; SNOWberG, L. K.; LaU, O. L. \& PAULL, J. S. 2010. Ecological release from interspecific competition leads to decoupled changes in population and individual niche width. Proceedings of the Royal Society Biological Sciences 277:1789-1797.

Bolnick, D. I.; Yang, L. H.; Fordyce, J. A.; Davis, J. M. \& SvanbäCK, R. 2002. Measuring individual-level resource specialization. Ecology 83:2936-2941.

Bouvier, L. D.; CotTenie, K. \& Doka, S. E. 2009. Aquatic connectivity and fish metacommunities in wetlands of the lower Great Lakes. Canadian Journal of Fisheries and Aquatic Sciences 66:933-948.

Bowen, S. H. 1983. Detritivory in neotropical fish communities. Environmental Biology of Fishes 9:137-144.

Carniatto, N.; Fugi, R.; Cantanhêde, G.; Gubiani, E. A. \& Hahn, N. S. 2012. Effects of flooding regime and diel cycle on diet of a small sized fish associated to macrophytes. Acta Limnologica Brasiliensia 24:363-372.

CorrêA, C. E.; Albrecht, M. P. \& Hahn, N. S. 2011. Patterns of niche breadth and feeding overlap of the fish fauna in the seasonal Brazilian Pantanal, Cuiabá River basin. Neotropical Ichthyology 9:637-646.

Correa, S. B. \& Winemiller, K. O. 2014. Niche partitioning among frugivorous fishes in response to fluctuating resources in the Amazonian floodplain forest. Ecology 95:210-224.

Davis, A. M.; Unmack, P. J.; Pusey, B. J.; Pearson, R. G. \& Morgan, D. L. 2013. Ontogenetic development of intestinal length and relationships to diet in an Australasian fish family (Terapontidae). BMC Evolutionary Biology 13:53.
Dias, R. M.; Bailly, D.; Antônio, R.; Suzuki, H. I. \& Agostinho, A. A 2005. Colonization of the Corumbá Reservoir (Corumbá River, Paraná River basin, Goiás State, Brazil) by the "lambari" Astyanax altiparanae (Tetragonopterinae; Characidae). Brazilian Archives of Biology and Technology 48:467-476.

Dittrich, J.; Dias, J. D.; Bonecker, C. C.; LansaC-TôHa, F. A. \& Padial, A. A. 2016. Importance of temporal variability at different special scales for diversity of floodplain aquatic communities. Freshwater Biology 61:316-327.

Downing, A. L.; Brown, B. L. \& Leibold, M. A. 2014. Multiple diversitystability mecanisms enhance population and community stability in aquatic food webs. Ecology 95:173-184.

Figueiredo, B. R. S.; Araujo, G. J. M.; Silva, M. J. \& Medeiros, E. S. F. 2015. Implications of low food availability on resource partitioning among three species of Cichlidae (Pisces: Perciformes) in a Brazilian semi-arid reservoir. Acta Limnologica Brasiliensia 27:93-104.

Fugi R.; Hahn, N. S. \& Agostinho, A. A. 1996. Feeding styles of five species of bottom-feeding fishes of the high Paraná River. Environmental Biology of Fishes 46:297-307.

Galina, A. B. \& HaHN, N. S. 2003. Comparação da dieta de duas espécies de Triportheus (Characidae, Triportheinae), em trechos do reservatório de Manso e lagoas do rio Cuiabá, Estado do Mato Grosso. Acta Scientiarum 25:345-352.

Gaspar da Luz, K. D. \& OKada, E. K. 1999. Diet and dietary overlap of three sympatric fish species in lakes of the upper Paraná River floodplain. Brazilian Archives of Biology and Technology 42:441-447.

Gelós, M.; Melo, F. T.; Goyenola, G.; Iglesias, C.; Fosalba, C.; GarcíaRodriguéz, F.; Pacheco, J. P.; García, S. \& Meerhoff, M. 2010. Seasonal and dial changes in fish activity and potential cascading effects in subtropical shallow lakes with different water transparency. Hydrobiologia 646:173-185.

Gerking, S. D. 1994. Feeding ecology of fish. New York, San Diego, Academic Press. 416p.

GoldBerg, D. E. \& SCHEINER, S. M. 1993. ANOVA and ANCOVA: Field competition experiments. In: ScheIner, S. M. \& Gurevitch, J. eds. Design and analysis of ecological experiments. New York, Chapman \& Hall, p. 69-93.

Gotelli, N. J. \& EnTSMinger, G. L. 2001. EcoSim: Null models software for ecology. Version 7.0. Acquired Intelligence Inc. \& Kesey-Bear. Available at $<\mathrm{http}: / /$ homepages.together.net/ gentsmin/ecosim.htm $>$.

Hellawell, L. M. \& ABEL, R. 1971. A rapid volumetric method for the analysis of the food of fishes. Journal of Fish Biology 48:29-37.

Hutchinson, G. E. 1957. Concluding remarks. Cold Spring Harbor Symposium on Quantitative Biology 22:415-427.

HysLop, E. J. 1980. Stomach contents analysis, a review of methods and their application. Journal of Fish Biology 17:411-429.

IvLEV, V. S. 1961. Experimental ecology of the feeding of fishes. New Haven, Yale University Press. 302p.

JACKSON, D. A.; Peres-Neto, P. R. \& Olden, J. D. 2001. What controls who is where in freshwater fish communities - the roles of biotic, abiotic, and spatial factors. Canadian Journal of Fisheries and Aquatic Sciences 58:157-170.

JunK, J. W.; BAYley, P. B. \& Sparks, R. E. 1989. The food pulse concept in river floodplain system. Canadian Journal of Fisheries and Aquatic 106:110-127.

LAWLOR, L. R. 1980. Overlap, similarity and competition coefficients. Ecology 61:245-251.

Legendre, P. \& Legendre, L. 1998. Numerical Ecology. Amsterdam, Elsevier Science. 852p.

Lowe-McConnell, R. H. 1987. Ecological studies in tropical fish communities. Cambridge, Cambridge University Press. 382p.

Lujan, N. K.; German, D. P. \& Winemiller, K. O. 2011. Do wood-grazing fishes partition their niche? Morphological and isotopic evidence for trophic segregation in Neotropical Loricariidae. Functional Ecology 25:1327-1338.

Luz-Agostinho, K. D. G.; Agostinho, A. A.; Gomes, L. C. \& JúLio JR. H. F. 2008. Influence of flood pulses on diet composition and trophic relationship among piscivorous fish in the upper Paraná River floodplain. Hydrobiologia 607:187-198. 
Luz-Agostinho, K. D. G.; Bini, L. M.; Fuji, R.; Agostinho, A. A. \& Júlio JR., H. F. 2006. Food spectrum and trophic structure of the ichthyofauna of Corumbá reservoir, Paraná river Basin, Brazil. Neotropical Ichthyology 4:61-68.

Marçal-Simabuku, M. A. \& Peret, A. C. 2002. Alimentação de peixes (Osteichthyes, Characiformes) em duas lagoas de uma planície de inundação brasileira da bacia do rio Paraná. Interciencia 27:299-306.

Martin, R. Y. \& Pfennig, D. W. 2010. Field and experimental evidence that competition and ecological opportunity promote resource polymorphism. Biological Journal of the Linnean Society 100:73-88.

Mateus, L.; Ortega, J.; Mendes, A. \& Penha, J. 2016. Nonlinear effect of density on trophic niche width and between-individual variation in diet in a neotropical cichlid. Austral Ecology 41(5):492-500.

Matthews, W. J. 1998. Patterns in freshwater fish ecology. New York, Chapman \& Hall. 756p.

McPeek, M. A. 2014. Limiting factors, competitive exclusion, and a more expansive view of species coexistence. The American Naturalist 183:iii-iv.

Medeiros, E. S. F. \& Arthington, A. H. 2014. Fish diet composition in floodplain lagoons of an Australian dryland river in relation to an extended dry period following flooding. Environmental Biology of Fishes 97:797-812.

MÉrona, B. \& RANKIN-DE-MÉrona, J. 2004. Food resource partitioning in a fish community of the central Amazon floodplain. Neotropical Ichthyology 2:75-84.

Monteiro, A. S.; Oliveira, A. H. M.; Pelicice, F. M. \& Oliveira, R. J. 2009. Alterações na disponibilidade de recursos alimentares e na dieta das principais espécies de peixes. In: Agostinho, C. S.; Pelicice, F. M. \& Marques, E. E. eds. Reservatório de Peixe Angical: bases ecológicas para o manejo da ictiofauna. São Carlos, RiMa, p. 77-86.

Olson, K. W.; Jensen, O. P. \& HrabiK, T. R. 2015. Feeding ecology and prey resource partitioning of lenok (Brachymystax lenok) Baikal grayling (Thymallus arcticus baicalensis) in the Eg and Uur rivers, Mongolia. Ecology of Freshwater Fish 25(4):565-576.

Pendleton, R. M.; Hoeinghaus, D. J.; Gomes, L. C. \& Agostinho, A. A. 2014. Loss of rare fish species from tropical floodplain food webs affects community structure and ecosystem multifunctionality in a mesocosm experiment. PLoS ONE 9:e84568.

Pereira, L. S.; Tencatt, L.; Dias, R. M.; Oliveira, A. G.; Agostinho, A. A. 2017. Effects of long and short flooding years on the feeding ecology of piscivorous fish in floodplain river systems. Hydrobiologia 796(1):65-80.

Petchey, O. L.; Brose, U. \& Rall, B. C. 2010. Predicting the effects of temperature on food web connectance. Phylosophycal Transactions of the Royal Society B 365:2081-2091.

Petry, A. C.; Agostinho, A. A. \& Gomes, L. C. 2003. Fish assemblages of tropical floodplain lagoons: exploring the role of connectivity in a dry year. Neotropical Ichthyology 1:111-119.
Polis, G. A. \& Winemiller, K. O. 1996. Food Webs: Integration of patterns and dynamics. New York, Chapman \& Hall. 475p.

Pusey, B. J.; Read, M. G. \& Arthington, A. H. 1995. The feeding ecology of freshwater fishes in two rivers of the Australian wet tropics. Environmental Biology of Fishes 43:85-103.

Rondinelli, G.; Gomiero, L. M.; CARmassi, A. L. \& Braga, F. M. S. 2011 Diet of fishes in Passa Cinco stream, Corumbataí River sub-basin, São Paulo state, Brazil. Brazilian Journal of Biology 71:157-167.

RöPke, C. P.; Ferreira, E. \& Zuanon, J. 2014. Seasonal changes in the use of feeding resources by fish in stands of aquatic macrophytes in an Amazonian floodplain, Brasil. Environmental Biology of Fishes 97:401-414.

Ross, S. T. 1986. Resource partitioning in fish assemblages: a review of field studies. Copeia 2:352-388.

Scarabotti, P. A.; López, J. A. \& Pouilly, M. 2011. Flood pulse and the dynamics of fish assemblage structure from neotropical floodplain lakes. Ecology of Freshwater Fish 20:605-618.

SCHOENER, T. W. 1968. The Anolis lizards of Bimini: resource partitioning in a complex fauna. Ecology 51:408-414

SCHOENER, T. W. 1974. Resource partitioning in ecological communities. Science 185:27-39.

SvanbäcK, R.; RydberG, C.; LeOnArdsson, K. \& Englund, G. 2011. Diet specialization in a fluctuating population of Saduria entomon: a consequence of resource or forager densities? Oikos 120:848-854.

Thomaz, S. M.; Bini, L. M. \& Bozelli, R. L. 2007. Floods increase similarity among aquatic habitats in river-floodplain systems. Hydrobiologia 579:1-13.

UiedA, V. S. \& PinTo, T. L. F. 2011. Feeding selectivity of ichthyofauna in a tropical stream: space-time variations in trophic plasticity. Community Ecology 12:31-39.

WINEMILLER, K. O. 1989. Ontogenetic diet shifts and resource partitioning among piscivorous fishes in the Venezuelan llanos. Environmental Biology of Fishes 26:177-199.

Winemiller, K. O. 1996. Factors driving temporal and spatial variation in aquatic floodplain food webs. In: Polis, G. A. \& Winemiller, K. O. eds. Food Webs: Integration of patterns and dynamics. New York, Chapman \& Hall, p. 298-312.

Winemiller, K. O.; Flecker, A. S. \& Hoeinghaus, D. J. 2010. Patch dynamics and environmental heterogeneity in lotic ecosystems. Journal of the North American Benthological Society 29:84-99.

Winemiller, K. O. \& Kelso-Winemiller, L. C. 1996. Comparative ecology of catfishes of the Upper Zambezi River floodplain. Journal of Fish Biology 49:1043-1061.

Wootton, R. L. 1999. Ecology of teleost fishes. London, The Netherlands, Kluwer Academic. 396p.

Zaret, N. T. \& RAND, A. S. 1971. Competition in tropical stream fishes: support for the competitive exclusion principle. Ecology 52:336-342. 